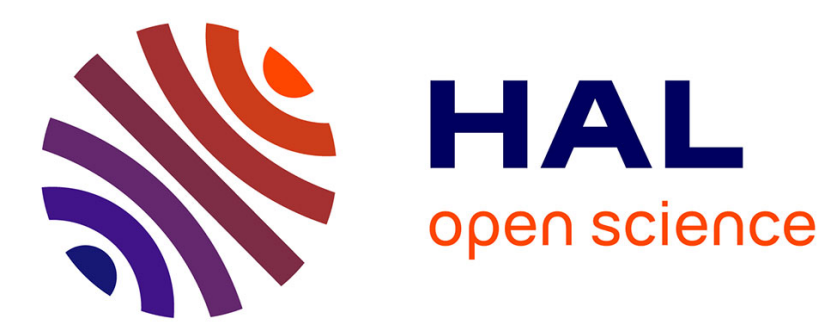

\title{
A scientific note on the isolation and characterization of microsatellite loci of Frieseomelitta varia (Hymenoptera, Apidae, Meliponini)
}

Paulo Gonçalves, Flávio Oliveira Francisco, Rute Brito, Alayne

Domingues-Yamada, Fabiana Pioker, Ademilson Soares, Maria Arias

\section{To cite this version:}

Paulo Gonçalves, Flávio Oliveira Francisco, Rute Brito, Alayne Domingues-Yamada, Fabiana Pioker, et al.. A scientific note on the isolation and characterization of microsatellite loci of Frieseomelitta varia (Hymenoptera, Apidae, Meliponini). Apidologie, 2011, 42 (5), pp.560-563. 10.1007/s13592-0110008-x . hal-01003617

\section{HAL Id: hal-01003617 https://hal.science/hal-01003617}

Submitted on 1 Jan 2011

HAL is a multi-disciplinary open access archive for the deposit and dissemination of scientific research documents, whether they are published or not. The documents may come from teaching and research institutions in France or abroad, or from public or private research centers.
L'archive ouverte pluridisciplinaire HAL, est destinée au dépôt et à la diffusion de documents scientifiques de niveau recherche, publiés ou non, émanant des établissements d'enseignement et de recherche français ou étrangers, des laboratoires publics ou privés. 


\title{
A scientific note on the isolation and characterization of microsatellite loci of Frieseomelitta varia (Hymenoptera, Apidae, Meliponini)
}

\author{
Paulo Henrique Pereira Gonçalves ${ }^{1}$, Flávio de Oliveira Francisco ${ }^{1}$, Rute Magalhães Brito ${ }^{1,4}$, \\ Alayne Magalhães Trindade Domingues-Yamada ${ }^{1}$, Fabiana Curtopassi Pioker ${ }^{2}$, \\ Ademilson Espencer Egea SoAREs ${ }^{3}$, Maria Cristina ARIAs ${ }^{1}$ \\ ${ }^{1}$ Departamento de Genética e Biologia Evolutiva, Instituto de Biociências, Universidade de São Paulo, Rua do Matão, \\ 277, São Paulo, SP 05508-090, Brazil \\ ${ }^{2}$ Departamento de Ecologia, Instituto de Biociências, Universidade de São Paulo, Rua do Matão, travessa 14, nº. 321, \\ São Paulo, SP 05508-900, Brazil \\ ${ }^{3}$ Departamento de Genética, Faculdade de Medicina de Ribeirão Preto, Universidade de São Paulo, Av. Bandeirantes, \\ 3900, Ribeirão Preto, SP 14049-900, Brazil \\ ${ }^{4}$ Instituto de Genética e Bioquímica, Universidade Federal de Uberlândia, Av. Pará, 1720, Uberlândia, \\ MG 38400-902, Brazil
}

Received 8 June 2010 - Revised 10 September 2010 - Accepted 23 September 2010

microsatellite / genomic library / Meliponini / allelic richness / Frieseomelitta varia

The environmental changes mediated directly or indirectly by humans represent a threat for many species. Most of the bee species build their nest in hollow of trees, so deforestation represents a great loss both in terms of number of species and in number of individuals (nests). The reduction of forest to fragments surrounded by urban areas may represent a severe barrier to gene flow leading to inbreeding and loss of genetic variability (Frankham et al. 2004). The assessment of the genetic structure of populations depends on the availability of reliable molecular markers. Studies aiming at characterizing stingless bee populations have been traditionally performed by using heterospecific microsatellite primers. It has been shown, however, that this strategy is not sensitive enough to detect polymorphism to perform robust population analysis (Francisco et al. 2006).

Corresponding author: P.H.P. Gonçalves, paulovirt@yahoo.com.br

*Manuscript editor: Klaus Hartfelder
The genus Frieseomelitta has a large geographic distribution ranging from Mexico to southern Brazil. It consists of 16 valid species from which ten are present in Brazil (Silveira et al. 2002). The species Frieseomelitta varia (Meliponini) has drawn attention by the presence of several nests in buildings housing the University of São Paulo facilities (in Ribeirão Preto, SP). This area is surrounded by residential areas or sugar cane crop where nests have not been found. Several questions concerning inbreeding, gene flow, genetic variability can be addressed using this small population as a model. Thus, aiming to answer these questions we isolated and characterized microsatellite loci from $F$ varia's genome, designed primers, and standardized PCR conditions.

Genomic DNA from a pool of ten females was obtained following a phenol/chlorophorm protocol. The microsatellite enriched genomic library was built following the procedure described by Billotte et al. (1999). Approximately $5 \mu \mathrm{g}$ of genomic DNA were digested with $50 \mathrm{U}$ of $R s a \mathrm{I}$. Fragments were linked to singlestrand adaptors (10 $\mu \mathrm{M}$ each): Rsa21 (5'CTCTTGCTTACGCG TGGACTA-3') and Rsa25 (5'- 


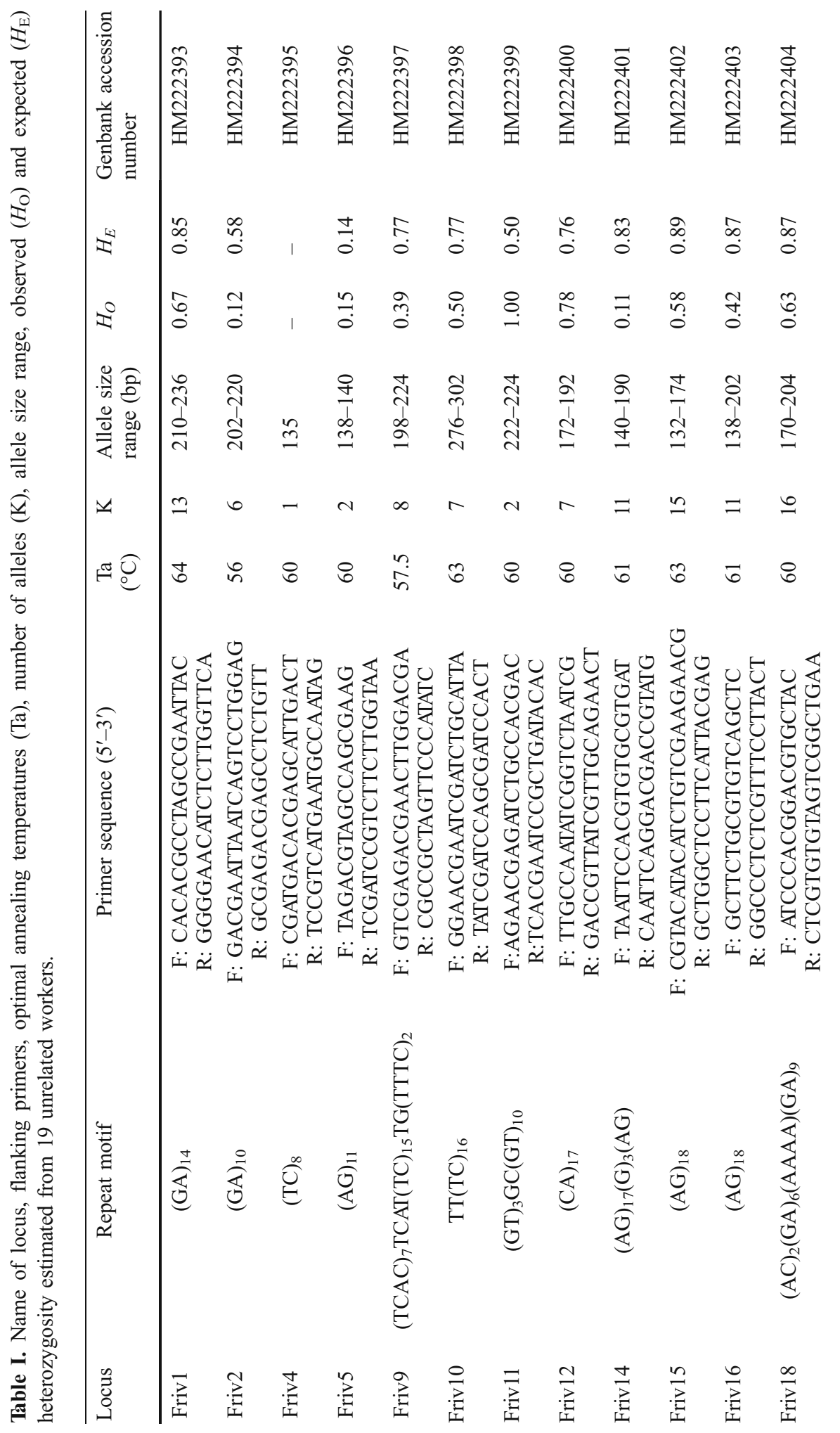


TAGTCCACGC GTAAGCAAGAGCACA-3'). Those fragments were amplified by using the Rsa21 adaptor as primer. The PCR products were screened for repeat motifs through hybridization with four biotinylated probes $\left[(\mathrm{CT})_{8},(\mathrm{GT})_{8},(\mathrm{GA})_{8}\right.$, and $\left.(\mathrm{AGA})_{5}\right]$. This selection was mediated by metallic micro beads (Streptavidin MagneSphere ${ }^{\circledR}$-Promega). The selected fragments were cloned into $\mathrm{pGem}^{\circledR}{ }^{\circledR} \mathrm{T}$ vector (Promega) and used to transform E. coli DH5 $\alpha$ cells. Positive clones (71) were sequenced in an automated sequencer (ABI Prism 3100). The sequences were visualized and screened for the presence of microsatellites using the BioEdit v. 7.0 software (Hall 1999). Seventeen primer pairs were designed (see Table I) using the Primer3 software (Rozen and Skaletsky 1998).

A sample of nineteen unrelated individuals of $F$. varia collected in different Brazilian regions was analyzed. Moreover, for detection of cross-specific amplifications, one individual of each of the following species was analyzed: Frieseomelitta flavicornis, Frieseomelitta doederleini, Frieseomelitta trichocerata, Paratrigona sp., Scaptotrigona postica, and Schwarziana quadripunctata. PCR reactions were carried out in a final volume of $10 \mu \mathrm{L}$ containing: $5.45 \mu \mathrm{L}$ of deionized $\mathrm{H}_{2} \mathrm{O} ; 2 \mu \mathrm{L}$ of betaine $5 \mathrm{M} ; 1 \mathrm{X}$ reaction buffer; $0.15 \mu \mathrm{L}$ of $\mathrm{MgCl}_{2} 50 \mathrm{mM} ; 0.2 \mu \mathrm{L}$ of each primer $10 \mu \mathrm{M}$; $1 \mathrm{U}$ of $\mathrm{Taq}$ polymerase (Invitrogen); and $1 \mu \mathrm{L}$ of template DNA obtained through phenol/chlorophorm extraction from one individual. Amplifications were performed in a GeneAmp ${ }^{\circledR}$ PCR System 9700 (Applied Biosystems) for $4 \mathrm{~min}$ at $94^{\circ} \mathrm{C}$, followed by 35 cycles of $40 \mathrm{~s}$ at $94^{\circ} \mathrm{C}, 50 \mathrm{~s}$ at specific annealing temperature (see Table I), and $40 \mathrm{~s}$ at $72^{\circ} \mathrm{C}$ with a final elongation step of $10 \mathrm{~min}$ at $72^{\circ} \mathrm{C}$. The amplified fragments were resolved by electrophoresis in $9 \%$ nondenaturing polyacrylamide gels and visualized by silver staining. A 100 bp DNA Ladder (Invitrogen) was used to estimate fragment sizes. Observed heterozygosity $(\mathrm{Ho})$, expected heterozygosity $(\mathrm{He})$, and number and frequency of alleles were calculated using FOFpop v.2.0 (Francisco 2009). As this study was performed with individuals sampled in geographically distant regions, tests for Hardy Weinberg and linkage disequilibrium were not applied.

The amplification analysis showed that 12 out of 17 primer pairs successfully amplified the respective loci, with 11 being polymorphic (Table I). So far, the average number of alleles found in this study (8.08) was the second highest in Meliponini. Higher values (8.94) were only described for the species Tetragonisca angustula (Brito et al. 2009). In contrast, studies applying ISSR methodology to isolate species specific microsatellite loci found only low levels of allelic richness, 3 and 2.63 for Melipona mondury and Melipona rufiventris, respectively (Lopes et al. 2009, 2010). Therefore, the methodology of an enriched genomic library seems to be more efficient, even though the low level of

Table II. Results from cross-species amplification tests: (+) amplification and (-) no amplification.

\begin{tabular}{|c|c|c|c|c|c|c|}
\hline Locus & $\begin{array}{l}\text { Frieseomelitta } \\
\text { flavicornis }\end{array}$ & $\begin{array}{c}\text { Frieseomelitta } \\
\text { doederleini }\end{array}$ & $\begin{array}{c}\text { Frieseomelitta } \\
\text { trichocerata }\end{array}$ & $\begin{array}{l}\text { Paratrigona } \\
\text { sp. }\end{array}$ & $\begin{array}{c}\text { Scaptotrigona } \\
\text { postica }\end{array}$ & $\begin{array}{c}\text { Schwarziana } \\
\text { quadripunctata }\end{array}$ \\
\hline Friv1 & + & + & + & + & + & + \\
\hline Friv2 & - & - & - & - & - & - \\
\hline Friv4 & + & + & + & + & + & + \\
\hline Friv5 & + & + & + & + & + & + \\
\hline Friv9 & + & + & + & + & + & + \\
\hline Friv10 & + & + & + & - & + & + \\
\hline Friv12 & + & + & + & + & + & - \\
\hline Friv14 & + & + & + & + & + & + \\
\hline Friv15 & + & + & + & + & - & + \\
\hline Friv16 & + & + & + & + & - & + \\
\hline Friv18 & + & + & + & + & + & + \\
\hline
\end{tabular}


polymorphism detected by Lopes et al. (2009, 2010) may be related to their sampling strategy. The authors analyzed 20 individuals from a single population of each species, whereas in our study we analyzed 19 unrelated individuals collected in different localities.

Expected and observed heterozygosities ranged from 0.14 to 0.89 (mean 0.69 ) and from 0.00 to 1.00 (mean 0.48), respectively. In general, the observed heterozygosity was lower than the expected, except for the loci Friv5, Friv11, and Friv12 (Table I).

The primer set presented herein is suitable for studies aiming at characterizing $F$ varia with respect to genetic diversity, relatedness, inbreeding levels, nest aggregations, intraspecific variation, and genetic mapping. Also, as the cross-species amplification tests revealed PCR fragments of expected size also for the other species analyzed we are confident that, with few exceptions (Table II), these loci will be suitable and informative in studies of other stingless bee species, and thus will contribute to a better understanding of the biology of $F$ varia, and for stingless bees in general.

\section{ACKNOWLEDGMENTS}

We would like to thank Dr. Anete P. de Sousa and students from CBMEG-UNICAMP for helping with the genomic library; Dr. Favízia Freitas de Oliveira for identification of specimens; Susy Coelho Oliveira for technical assistance; FAPESP (BIOTA 2004/15801$0)$, CAPES, and CNPq for financial support and scholarships.

\section{Note scientifique sur l'isolation et la caractérisation de microsatellites de Frieseomelitta varia (Hyme- noptera, Apidae, Meliponini)}

Eine wissenschaftliche Notiz über die Isolierung und Characterisierung von 112 MikrosatellitenLoci von Frieseomelitta varia(Hymenoptera, Apidae, Meliponini)

\section{REFERENCES}

Billotte, N., Lagoda, P.J.R., Risterucci, A.M., Baurens, F.C. (1999) Microsatellite-enriched libraries: applied methodology for the development of SSR markers in tropical crops. Fruits 54, 277-288

Brito, R.M., Francisco, F.O., Domingues-Yamada, A.M.T., Gonçalves, P.H.P., Pioker, F.C., Soares, A.E.E., Arias, M.C. (2009) Characterization of microsatellite loci of Tetragonisca angustula (Hymenoptera, Apidae, Meliponini). Conserv. Genet. Resour. 1, 183-187

Francisco, F.O., Brito, R.M., Arias, M.C. (2006) Alelle number and heterozygosity for microsatellite loci in different stingless bee species (Hymenoptera: Apidae, Meliponini). Neotrop. Entomol. 35, 638-643

Francisco, F.O. (2009) FOFpop v.2.0, a pool of Microsoft Excel sheets to analyze genotypic data. Available at http://www.ib. usp.br/ lgea/fofpop

Frankham, R., Ballou, J.D., Briscoe, D.A. (2004) A primer of conservation genetics. Cambridge University Press, Cambridge

Hall, T.A. (1999) BioEdit: a user-friendly biological sequence alignment editor and analysis program for Windows 95/98/NT. Nucleic Acids Symp Ser. 41, 95-98

Lopes, D.M., Silva, F.O., Fernandes-Salomão, T.M., Campos, L.A.O., Tavares, M.G. (2009) Microsatellite loci for the stingless bee Melipona rufiventris (Hymenoptera: Apidae). Mol. Ecol. Resour. 9, 923-925

Lopes, D.M., Silva, F.O., Fernandes-Salomão, T.M., Campos, L.A.O., Tavares, M.G. (2010) A scientific note on the characterization of microsatellite loci for Melipona mondury (Hymenoptera: Apidae). Apidologie 41, 138-140

Rozen, S., Skaletsky, H.J. (1998) Primer3. Code available at http://www-genome.wi.mit.edu/genome_software/other/ primer3.html

Silveira, F.A., Melo, G.A.R., Almeida, E.A.B. (2002) Abelhas brasileiras-sistemática e identificação. Editora Composição e Arte, Minas Gerais 